\title{
DECISÃO JURÍDICA EM TEMPOS PÓS-POSITIVISTAS
}

\section{LENIO LUIZ STRECK*}

\begin{abstract}
RESUMO: A hermenêutica filosófica tem sido impropriamente criticada pelo fato de que, embora tenha oferecido o modo mais preciso de descrição do processo compreensivo, não teria possibilitado a formação de uma teoria da decisão. Não há dúvida de que uma teoria jurídica democrática deve se preocupar com a validade normativo-jurídica do juízo decisório, mas isso não significa uma "proibição de interpretar". O que se pretende é mostrar como persistem equívocos nas construções epistêmicas atuais e como tais equívocos se dão em virtude do uso aleatório das posições dos vários autores que compõe o chamado pós-positivismo, porquanto só se pode chamar de pós-positivista uma teoria do direito que tenha, efetivamente, superado o positivismo, ou seja, superado o problema da discricionariedade judicial. A tarefa hermenêutica é, portanto, construir as condições para a elaboração de uma teoria da decisão jurídica, discutindo-se as possibilidades de elaboração de um efetivo controle das decisões judiciais.
\end{abstract}

PALAVRAS-CHAVE: Decisão Judicial; Positivismo; Pós-positivismo; Hermenêutica Filosófica; Teoria da Decisão.

ABSTRACT: The philosophical hermeneutics has been improperly criticized by the fact that, although it offered the most accurate way to describe the comprehensive process, would not have allowed the formation of a Theory of Judicial Decision. There's no doubt that a democratic legal theory must be concerned with the normative-legal validity of decision, but this does not mean a "ban on interpreting". The aim is to show how misconceptions persist in the current epistemic constructions and how such mistakes occur due to the use of random positions of the various authors who make up the socalled post-positivism, since it can only be called a post-positivist theory of law that has effectively overcome positivism, ie, overcome the problem of judicial discretion. So, the hermeneutic task is building the conditions for developing a Theory of Judicial Decision, discussing the possibilities of elaborating an effective control of judgments.

KEYWORDS: Judicial Decision; Legal Positivism; Postpositivism; Philosophical hermeneutics; Theory of Judicial Decision.

SUMÁRIO: 1. Um necessário retorno a Kelsen: desmi(s)tificando o(s) positivismo(s); 2. O problema da validade do discurso jurídico; 3 . Há uma teoria da validade na hermenêutica?; 4. As críticas à hermenêutica e o problema da má compreensão do sentido de "pré-compreensão" (Vorverständnis); 5. Ainda o mesmo problema, agora sob outra perspectiva; 6. À guisa de considerações finais; Referências Bibliográficas.

Artigo recebido em 20.06.2010. Pareceres emitidos em 22.09.2010 e 26.09.2010.

Artigo aprovado para publicação em 29.09.2010.

* Presidente de Honra do IHJ. Membro catedrático da ABDCONST. Doutor em Direito pela UFSC. Pós-Doutor em Direito Constitucional pela Universidade de Lisboa. Professor da Unisinos e da Unesa. Professor Visitante da Universidade de Roma TRE e FDUC (Coimbra). 
SUMMARY: 1. A necessary return to Kelsen: demystifying positivism(s); 2. The problem of legal discourse validity; 3 . Is there a theory of validity in hermeneutics?; 4. Criticisms to hermeneutics and the problem of misunderstanding the meaning of "pre-understanding" (Vorverständnis); 5. Still the same problem, now from another perspective; 6. Final reflections; References.

\section{UM NECESSÁRIO RETORNO A KELSEN: DESMI(S)TIFICANDO O(S) POSITIVISMO(S)}

Quando falamos em positivismos e pós-positivismos, torna-se necessário, já de início, deixar claro o "lugar da fala", isto é, sobre "o quê" estamos falando. Com efeito, de há muito minhas críticas são dirigidas primordialmente ao positivismo normativista pós-kelseniano, isto é, ao positivismo que admite discricionariedades (ou decisionismos e protagonismos judiciais). Isto porque considero, no âmbito destas reflexões e em obras como Verdade e Consenso, ${ }^{1}$ superado o velho positivismo exegético. Ou seja, não é (mais) necessário dizer que o “juiz não é a boca da lei”, etc, enfim, podemos ser poupados, nesta quadra da história, dessas "descobertas polvolares". Isto porque essa "descoberta" não pode implicar um império de decisões solipsistas, das quais são exemplos as posturas caudatárias da jurisprudência dos valores (que foi "importada" de forma equivocada da Alemanha), os diversos axiologismos, o realismo jurídico (que não passa de um "positivismo fático"), etc..

Explicando melhor: o positivismo é uma postura científica que se solidifica de maneira decisiva no século XIX. O "positivo" a que se refere o termo positivismo é entendido aqui como sendo os fatos (lembremos que o neopositivismo lógico também teve a denominação de "empirismo lógico"). Evidentemente, fatos, aqui, correspondem a uma determinada interpretação da realidade que engloba apenas aquilo que se pode contar, medir ou pesar ou, no limite, algo que se possa definir por meio de um experimento.

No âmbito do direito, essa mensurabilidade positivista será encontrada, num primeiro momento, no produto do parlamento, ou seja, nas Leis, mais especificamente, num determinado tipo de lei: os Códigos. É preciso destacar que esse legalismo apresenta notas distintas na medida em que se olha esse fenômeno numa determinada tradição jurídica (como exemplo, podemos nos referir: ao positivismo inglês, de cunho utilitarista; ao positivismo francês, onde predomina um exegetismo da legislação; e ao alemão, no interior do qual é possível perceber o florescimento do chamado formalismo conceitual que se encontra na raiz da chamada jurisprudência dos conceitos). No que tange às experiências francesas e alemãs, isso pode ser debitado à forte influência que o direito romano exerceu na formação de seus respectivos direito privado. Não em virtude do que comumente se pensa - de que os romanos "criaram as leis escritas" -, mas, sim, em virtude do modo como o direito romano era estudado e ensinado. Isso que se chama de exegetismo tem sua origem aí: havia um texto específico em torno do qual giravam os mais sofisticados estudos sobre o direito. Este texto era - no período pré-codificação - o Corpus Juris Civilis. A codificação

${ }^{1}$ Cf. STRECK, Lenio Luiz. Verdade e Consenso. 3. ed. Rio de Janeiro: Lumen Juris, 2009. 
efetua a seguinte "marcha": antes dos códigos, havia uma espécie de função complementar atribuída ao Direito Romano. A ideia era simples, aquilo que não poderia ser resolvido pelo Direito Comum, seria resolvido segundo critérios oriundos da autoridade dos estudos sobre o Direito Romano - dos comentadores ou glosadores. O movimento codificador incorpora, de alguma forma, todas as discussões romanisticas e acaba "criando" um novo dado: os Códigos Civis (França, 1804 e Alemanha, 1900).

A partir de então, a função de complementariedade do direito romano desaparece completamente. Toda argumentação jurídica deve tributar seus méritos aos códigos, que passam a possuir, pois, a estatura de verdadeiros "textos sagrados". Isso porque eles são o dado positivo com o qual deverá lidar a Ciência do Direito. É claro que, já nesse período, apareceram problemas relativos à interpretação desse “texto sagrado”.

De algum modo se perceberá que aquilo que está escrito nos Códigos não cobre a realidade. Mas, então, como controlar o exercício da interpretação do direito para que essa obra não seja "destruída”? E, ao mesmo tempo, como excluir da interpretação do direito os elementos metafísicos que não eram bem quistos pelo modo positivista de interpretar a realidade? Num primeiro momento, a resposta será dada a partir de uma análise da própria codificação: a Escola da Exegese, na França, e a Jurisprudência dos Conceitos, na Alemanha.

Esse primeiro quadro eu menciono, no contexto de minhas pesquisas - e aqui talvez resida parte do "criptograma do positivismo -, como positivismo primevo ou positivismo exegético. Poderia ainda, junto com Castanheira Neves, nomeá-lo como positivismo legalista. A principal característica desse "primeiro momento" do positivismo jurídico, no que tange ao problema da interpretação do direito, será a realização de uma análise que, nos termos propostos por Rudolf Carnap, poderíamos chamar de sintático. Neste caso, a simples determinação rigorosa conexão lógica dos signos que compõem a "obra sagrada” (Código) seria o suficiente para resolver o problema da interpretação do direito. Assim, conceitos como o de analogia e princípio gerais do direito devem ser encarados também nessa perspectiva de construção de um quadro conceitual rigoroso que representariam as hipóteses - extremamente excepcionais - de inadequação dos casos às hipóteses legislativas.

Num segundo momento, aparecem propostas de aperfeiçoamento desse "rigor" lógico do trabalho científico proposto pelo positivismo. É esse segundo momento que podemos chamar de positivismo normativista. Aqui há uma modificação significativa com relação ao modo de trabalhar e aos pontos de partida do "positivo", do "fato". Primeiramente, as primeiras décadas do século XX viram crescer, de um modo avassalador, o poder regulatório do Estado - que se intensificará nas décadas de 30 e 40 - e a falência dos modelos sintático-semânticos de interpretação da codificação se apresentaram completamente frouxos e desgastados. O problema da indeterminação do sentido do Direito aparece, então, em primeiro plano.

É nesse ambiente que aparece Hans Kelsen. Por certo, Kelsen não quer destruir a tradição positivista que foi construída pela jurisprudência dos conceitos. Pelo contrário, é possível afirmar que seu principal objetivo era reforçar o método analítico proposto pelos conceitualistas de modo a responder ao crescente desfalecimento do rigor jurídico 
que estava sendo propagado pelo crescimento da Jurisprudência dos Interesses e à Escola do Direito Livre - que favoreciam, sobremedida, o aparecimento de argumentos psicológicos, políticos e ideológicos na interpretação do direito. Isso é feito por Kelsen a partir de uma radical constatação: o problema da interpretação do direito é muito mais semântico do que sintático. Desse modo, temos aqui uma ênfase na semântica.

Mas, em um ponto específico, Kelsen “se rende” aos seus adversários: a interpretação do direito é eivada de subjetivismos provenientes de uma razão prática solipsista. Para o autor austríaco, esse “desvio” é impossível de ser corrigido. No famoso capítulo VIII de sua Teoria Pura do Direito, Kelsen chega a falar que as normas jurídicas - entendendo norma no sentido da TPD, que não equivale, stricto sensu, à lei - são aplicadas no âmbito de sua "moldura semântica". O único modo de corrigir essa inevitável indeterminação do sentido do direito somente poderia ser realizada a partir de uma terapia lógica - da ordem do a priori - que garantisse que o Direito se movimentasse em um solo lógico rigoroso. Esse campo seria o lugar da Teoria do Direito ou, em termos kelsenianos, da Ciência do Direito. E isso possui uma relação direta com os resultados das pesquisas levadas a cabo pelo Círculo de Viena.

Com efeito, como já mostrou Warat, Kelsen tem um tributo epistemológico principalmente com Carnap e isso fica muito claro quando Kelsen escolhe fazer ciência apenas na ordem das proposições jurídicas (ciência), deixando de lado o espaço da "realização concreta do direito". Com efeito, nos termos propostos por Manfredo Oliveira, também Carnap excluía de sua construção teórica a análise dos enunciados chamados pragmáticos: para Carnap, apenas e sintaxe e a semântica eram as dimensões da linguagem que interessavam ao labor filosófico. A pragmática, sendo uma ciência empírica, estava excluída da filosofia. ${ }^{2}$ Kelsen, portanto, privilegiou em seus esforços teóricos as dimensões semânticas e sintáticas dos enunciados jurídicos, deixando a pragmática para um segundo plano: o da discricionariedade do intérprete. Esse ponto é fundamental para poder compreender o positivismo que se desenvolveu no século XX e de que modo encaminho minhas críticas em minhas pesquisas. Falo desse positivismo normativista, não de um exegetismo que, como pôde ser demonstrado, já havia dado sinais de exaustão no início do século passado. Numa palavra: Kelsen já havia superado o positivismo exegético, mas abandonou o principal problema do direito - a interpretação concreta, no nível da “aplicação”.

\section{O PROBLEMA DA VALIDADE DO DISCURSO JURÍDICO}

Assentados esses esclarecimentos, ou seja, de que não é mais adequado falar em "superação do juiz boca da lei” e, sim, de investigar o modo como podemos controlar esse “juiz-que-já-não-é-a-boca-da-lei”, torna-se necessário enfrentar alguns pontos de "entulhamento significativo" no âmbito da teoria do direito. A equivocada compreensão do alcance e do papel da hermenêutica filosófica - matriz teórica a qual me filio (com as adaptações a partir da tese que proponho no sentido de que há um direito fundamental à obtenção de respostas corretas/adequadas à Constituição é um desses problemas. Com efeito, a hermenêutica filosófica tem sido -

${ }^{2}$ Cf. OLIVEIRA, Manfredo Araújo de. Reviravolta Lingüístico-pragmática na Filosofia Contemporânea. São Paulo: Loyola, 2001, p. 82-83. 
impropriamente - criticada pelo fato de que, embora ela tenha oferecido o modo mais preciso de descrição do processo compreensivo, por outro lado, ela não teria possibilitado a formação (normativa) de uma teoria da validade da compreensão assim obtida. Esse é um problema central que precisa ser enfrentado com muito cuidado. Trata-se de discutir as condições para a existência de uma teoria da decisão, o que implica discutir o problema da validade daquilo que se compreende e explicita na resposta. Afinal, interpretar é explicitar o compreendido, segundo Gadamer.

Validade foi, sem dúvida nenhuma, a expressão de ordem das teorias do direito surgidas na primeira metade do século XX. Através deste termo queria-se apontar para as possibilidades de determinação da verdade de uma proposição produzida no âmbito do direito. Ou seja, no contexto das teorias do direito que emergiram nesta época, a preocupação estava em determinar as condições de possibilidade para a formação de uma ciência jurídica. Assim, penso que, para se pensar em uma ciência jurídica, primeiro é preciso estar de posse de um contexto de significados que nos permitam dizer a conexão interna que existe entre verdade e validade.

Para o positivismo de matriz kelseniana, o vínculo entre verdade e validade dava-se da seguinte maneira: a validade é atributo das normas jurídicas, enquanto prescrições objetivas da conduta; ao passo que a verdade é uma qualidade própria das proposições jurídicas que, na sistemática da Teoria Pura do Direito, descrevem - a partir de um discurso lógico - as normas jurídicas. Ou seja, novamente estamos diante da principal operação epistemológica operada por Kelsen, que é a cisão entre Direito e Ciência Jurídica. O Direito é um conjunto sistemático de normas jurídicas válidas; enquanto a Ciência Jurídica é um sistema de proposições verdadeiras ${ }^{3}$. Disso decorre o óbvio: normas jurídicas ou são válidas ou inválidas; proposições jurídicas são verdadeiras ou falsas.

A aferição da validade é feita a partir da estrutura supra-infra-ordenada (lembro aqui da metáfora da pirâmide, embora Kelsen nunca tenha se referido desta forma ao ordenamento jurídico) que dá suporte para o escalonamento das normas jurídicas. Desse modo, uma norma jurídica só será válida se puder ser subsumida a outra - de nível superior - que lhe ofereça um fundamento de validade. Assim, a sentença do juiz é válida quando pode ser subsumida a uma lei - em sentido lato -, e a lei é válida porque pode ser subsumida à Constituição. Já a validade da Constituição advém da chamada norma hipotética fundamental, que, por sua vez, deve ter sua validade pressuposta. Isto porque, se continuasse a regredir em uma cadeia normativa autorizativa da validade da norma aplicanda, a Teoria Pura nunca conseguiria chegar a um fundamento definitivo, pois sempre haveria a possibilidade da construção de outro fundamento e isso repetido ao infinito. Assim, Kelsen oferece a tautologia como forma de rompimento com esta cadeia de fundamentação: a norma fundamental hipotética é porque é, por isso se diz que sua validade é pressuposta ${ }^{4}$.

${ }^{3}$ Cf. Kelsen, Hans. Teoria Pura do Direito. Tradução de João Baptista Machado. São Paulo: Martins Fontes, 1985, pp. 78 e segs.

${ }^{4}$ Para uma crítica pormenorizada ao problema do fundamento e a Grundnorm kelseniana, consultar Streck, Lenio Luiz. Jurisdição Constitucional e Hermenêutica. 2. ed. Rio de Janeiro: Forense, 2004. 
Ocorre que a relação de validade - que autoriza a aplicação da norma, fundamentando-a - não comporta uma análise lógica na qual a pergunta seria por sua verdade ou falsidade. Como afirma Kelsen: “as normas jurídicas como prescrições, isto é, enquanto comandos, permissões, atribuições de competência, não podem ser verdadeiras nem falsas”5 (porque elas são válidas ou inválidas - acrescentei). Desse modo, o jusfilósofo austríaco indaga: como é que princípios lógicos como o da nãocontradição e as regras de concludência do raciocínio podem ser aplicados à relação entre normas? A resposta de Kelsen é a seguinte: "os princípios lógicos podem ser, se não direta, indiretamente, aplicados às normas jurídicas, na medida em que podem ser aplicados às proposições jurídicas que descrevem estas normas e que, por sua vez, podem ser verdadeiras ou falsas". ${ }^{6}$ É dessa maneira que Kelsen liga verdade e validade, pois, no momento em que as proposições que descrevem as normas jurídicas se mostrarem contraditórias, também as normas descritas o serão e a determinação de qual proposição é a verdadeira, por consequência, determinará qual norma será igualmente válida.

Já no chamado "positivismo moderado”, de Herbert Hart, algumas diferenças são notadas. No que tange ao predomínio da determinação da validade com critério absoluto para determinação de fundamento do direito, não há grandes dessemelhanças. Porém, é na forma como Hart formula o fundamento do ordenamento jurídico que as divergências entre o seu modelo teórico e aquele fornecido por Kelsen aparecem com maior evidência. Com efeito, vimos que Kelsen resolve o problema do regresso ao infinito de seu procedimento dedutivista para determinação da validade com uma tautológica norma hipotética fundamental. Ou seja, ele se mantém no nível puramente abstrato da cadeia de validade de seu sistema e resolve o problema do fundamento neste mesmo nível, a partir de uma operação lógica.

Já Hart usará outro expediente para resolver o problema do fundamento. Na sua descrição do ordenamento jurídico, identificará a existência de dois tipos distintos de regras (normas): as primárias e as secundárias. As chamadas regras primárias são aquelas que determinam direitos e obrigações para uma determinada comunidade política. Tais regras seriam aquelas que estabelecem o direito de propriedade, de liberdade etc. Já as regras secundárias são aquelas que autorizam a criação de regras primárias. Neste caso, uma regra que estipule como deverão ser feitos os testamentos, é um exemplo de uma regra secundária e todas as regras que criem órgãos, estabeleçam competências ou fixem determinados conteúdos que deverão ser regulados concretamente pelas autoridades jurídicas também são consideradas regras secundárias. Portanto, o que determina a validade do direito, em Hart, é a compatibilização - dedutivista, evidentemente - das regras que determinam obrigações (primárias) com as regras secundárias ${ }^{7}$.

Hart afirma ainda que, em sociedades menos complexas - sendo que por sociedades menos complexas devem ser entendidas todas aquelas que antecedem a

${ }^{5}$ Kelsen, Hans. Idem, Ibidem, p. 82

${ }^{6}$ Cf. Kelsen, Hans. Idem, Ibidem.

${ }^{7}$ Cf. Hart, Hebert. O Conceito de Direito. Tradução de A. Ribeiro Mendes. 3. ed. Lisboa: Calouste Gulbenkian, 1996, pp. 89 e segs. 
modernidade -, não existiam regras secundárias desenvolvidas com a sofisticação que encontramos em nosso contexto atual. Neste caso, estas sociedades primitivas baseavam suas regras de obrigação apenas em critérios de aceitação. Como afirma Dworkin, "uma prática contém a aceitação (grifei) de uma regra somente quando os que seguem essa prática reconhecem a regra como sendo obrigatória e como uma

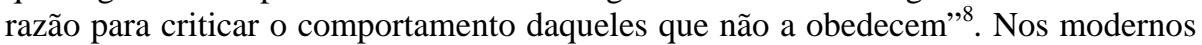
sistemas jurídicos, toda fundamentação do direito depende da articulação do conceito de validade. No entanto, há uma única regra - que Dworkin chama de "regra secundária fundamental" - que rompe com a necessidade de demonstração da validade e se baseia em critérios de aceitação para determinação de seu fundamento: trata-se da chamada regra de reconhecimento. Em síntese: a regra de reconhecimento está para Hart assim como a norma hipotética fundamental está para Kelsen: em ambos os casos funcionam como resposta para o problema do fundamento último do sistema jurídico. Todavia, a regra de reconhecimento tem um caráter mais "sociológico" do que a norma hipotética fundamental kelseniana. Como afirma Hart: "sua existência (da regra de reconhecimento - acrescentei) é uma questão de facto"9.

Mas o que há de errado com os projetos positivistas de ciência jurídica? Com Heidegger, podemos dizer que esse conceito corrente de ciência (como um universo teórico de proposições válidas-verdadeiras) esconde um modo mais originário do fenômeno da verdade. Isso porque a verdade deve ser percebida já em meio à lida com o mundo prático e não reduzida ao universo teorético das ciências. Afinal, a própria verdade "teórica" das ciências é produto da interpretação projetada pela compreensão.

Portanto, há algo anterior à verdade da ciência que, de certa forma, lhe é condição de possibilidade. No caso do direito, o equívoco dos projetos positivistas está no próprio recorte na totalidade do ente que tais teorias efetuam para caracterizar o estudo do fenômeno jurídico. Dito de outro modo, o modelo excessivamente teórico de abordagem gera uma espécie de asfixia da realidade, do mundo prático. Ou seja, o contexto prático das relações humanas concretas, de onde brota o direito, não aparece no campo de análise das teorias positivistas. Isso gera problema de diversos matizes. O fato de nenhuma das duas teorias conseguir resolver o problema da eficácia do sistema pode ser elencado com um destes problemas.

Para mim, entretanto, o principal problema aparece quando se procura determinar como ocorre e dentro de quais limites deve ocorrer a decisão judicial. Ambas as teorias apostam na vontade do intérprete para resolver o problema gerando a discricionariedade judicial. Ora, evidente que tais teorias sofrem de um letal déficit democrático. Pergunto: como justificar, legitimamente, uma decisão tomada pelo poder judiciário? Isso tais teorias não respondem. E nem poderiam responder, uma vez que essa dimensão dos acontecimentos fica fora de seu campo de análise.

Dizendo de outro modo - e venho insistindo nesse ponto - essa problemática

${ }^{8}$ Cf. Dworkin, Ronald. Levando os Direitos a Sério. Tradução de Nelson Boeira. São Paulo: Martins Fontes, 2002, p. 32.

${ }^{9}$ Cf. Hart, Herbert. O Conceito de Direito. op., cit., p. 121. 
da "validade da explicitação da compreensão" (portanto, da validade da interpretação) deve ser analisada a partir da destruição do método que é proporcionada por Gadamer. Com efeito, não há nisso um déficit de metodologia ou de racionalidade. Essa ruptura não significou um ingresso na irracionalidade ou no relativismo filosófico. Muito pelo contrário. Assim como a integridade em Dworkin, a hermenêutica está fundada na autoridade da tradição, que pode ser autêntica e inautêntica, além da importância do texto (que, em Gadamer, é um evento, como já demonstrei em Verdade e Consenso ${ }^{10}$ ). Gadamer deixa claro que a ausência do método não significa que se possa atribuir sentidos arbitrários aos textos. Na medida em que a interpretação sempre se dá em um caso concreto, não apenas fica nítida a impossibilidade de cisão entre quaestio facti e quaestio juris. A hermenêutica não trata apenas da faticidade; ela não apenas explica como se dá o sentido ou as condições pelas quais compreendemos. Na verdade, por ela estar calcada na circularidade hermenêutica, fato e direito se conjuminam em uma síntese, que somente ocorre concretamente, na applicatio (lembremos sempre que não se cinde conhecimento, interpretação e aplicação). Se interpretar é explicitar o que compreendemos, a pergunta que se faz é: essa explicitação seria o locus da validade? Se verdadeira essa assertiva - e creio que não é - então estaríamos diante de outro problema: o que fazer com a quaestio facti?

\section{HÁ UMA TEORIA DA VALIDADE NA HERMENÊUTICA?}

Ao contrário do que se apregoa, tenho que a hermenêutica filosófica, assim como a teoria integrativa dworkiniana, tratam adequadamente de uma teoria da decisão. A diferença é que ambas não admitem aquilo que está no cerne da expressiva maioria das teorias jurídicas contemporâneas: a discricionariedade dos juízes. Se a hermenêutica e a teoria integrativa não se preocupassem com a decisão, estas seriam relativistas, admitindo várias respostas para cada problema jurídico. Não há dúvida de que uma teoria jurídica democrática deve se preocupar com a validade normativo-jurídica do concreto juízo decisório. O que não se pode concordar é que, para alcançar esse juízo decisório, são possíveis juízos discricionários, o que reforça(ria) novamente o solipsismo interpretativo.

Numa palavra: a questão da validade reside na circunstância de que não podemos simplesmente confundir essa validade com uma espécie de imposição ontológica (no sentido clássico) nas questões com que se ocupam determinados campos do conhecimento cientifico. Também não podemos mais pensar a validade como uma cadeia causal sucessiva que tornaria verdadeiro um determinado conjunto de proposições jurídicas. A validade é o resultado de determinados processos de argumentação em que se confrontam razões e se reconhece a autoridade de um argumento.

E que fique bem claro que o reconhecimento da autoridade de um argumento não está ligado a uma imposição arbitrária. Pelo contrário, a hermenêutica é incompatível com qualquer tipo de arbitrariedade. Como afirma Gadamer - ao proceder a reabilitação da autoridade da tradição: “o reconhecimento da autoridade está sempre ligado à ideia de que o que a autoridade diz não é uma arbitrariedade irracional, mas algo que pode ser inspecionado principalmente. É nisso que consiste a essência da autoridade

${ }^{10}$ Cf. Streck, Verdade e Consenso, op.cit. 
que exige o educador, o superior, o especialista”. ${ }^{11}$ A partir disso, devemos primeiro compreender o problema da validade como uma questão que pode ser amplamente desenvolvida pela ciência e pela lógica. Mas não há duvida de que aqui também reaparece um certo tipo de pressuposto que está sempre presente para produzir o campo comum de interação próprio para troca de argumentos.

Mas penso que também poderíamos discutir o problema da validade em outro nível. Sob esse aspecto, a validade foi durante o neokantismo muitas vezes apresentada como o sentido que sustenta qualquer teoria dos enunciados. É desse conceito de validade que Heidegger extrai a necessidade de se fazer uma distinção entre a validade na ciência e a validade na filosofia, questão que ele, sob certos aspectos, utilizou para se inspirar na lenta determinação do que significa a diferença ontológica, na medida em que a validade que se coloca no nível dos entes é a validade para a qual nós temos instrumentos de argumentação/discussão, enquanto a outra validade termina já sempre operando nesses tipos de argumentação, que é o sentido. E esse sentido dos neokantianos passou em Heidegger precipuamente no conceito de ser. Por isso, para alguns autores, a diferença ontológica nasceu de uma leitura que Heidegger fez de certas discussões neokantianas. ${ }^{12}$

É preciso entender que a hermenêutica (filosófica) - e Dworkin segue essa mesma reflexão - (re)valoriza a dimensão prática da retórica oferecendo a possibilidade de instauração de um ambiente no qual os problemas da realidade são resolvidos concretamente, no interior desta mesma realidade, e não numa instância superior, de cunho ideal que, posteriormente, passa a ser aplicada por mimetismo à realidade. Note-se, por exemplo, que as críticas de que existe um excesso de abstração na teoria de Dworkin apresentam um equívoco de base: a orientação filosófica de Dworkin vai em direção a uma análise pragmática da realidade. Tal acusação poderia ser feita às teorias argumentativas e epistemo-procedurais, mas não a Dworkin ou à hermenêutica filosófica.

Em defesa de Dworkin - circunstância que pode ser estendida à hermenêutica filosófica -, é preciso lembrar que, enquanto um procedimentalista como Habermas desonera os juízes da elaboração dos discursos de fundamentação - porque desacredita na possibilidade de os juízes poderem se livrar da razão prática (eivada de solipsismo)-, ele (Dworkin) ataca esse problema a partir da responsabilidade política de cada juiz/intérprete/aplicador, obrigando-o (has a duty to) a obedecer à integridade do direito, evitando que as decisões se baseiem em raciocínios ad hoc (teleológicos, morais ou de política).

Insista-se: quando Dworkin diz que o juiz deve decidir lançando mão de argumentos de princípio e não de políticas, não é porque esses princípios sejam ou estejam elaborados previamente, à disposição da “comunidade jurídica” como enunciados

${ }^{11}$ Cf. Gadamer, Hans-Georg. Verdade e Método. Traços Fundamentais de uma Hermenêutica Filosófica. Tradução de Flávio Paulo Meurer. 3. ed. Petrópolis: Vozes, 1999, p. 420.

12 Também Stein aponta para este fato indicado no texto: “a diferença ontológica, cuja envergadura se desdobrou muito com o labor do filósofo, lhe foi ao menos possibilitada pelas análises de Emil Lask. O pensamento de Heidegger que se quer nos antípodas do problema gnosiológico, contudo, lhe deve algo de essencial” (Cf. Stein, Ernildo. Uma Breve Introdução à Filosofia. 2. ed. Ijuí: Unijuí, 2005, p. 83). 
assertóricos ou categorias (significantes primordiais-fundantes). Na verdade, quando sustenta essa necessidade, apenas aponta para os limites que devem haver no ato de aplicação judicial (por isso, ao direito não importa as convicções pessoais/morais do juiz acerca da política, sociedade, esportes, etc; ele deve decidir por princípios). É preciso compreender que essa "blindagem" contra discricionarismos é uma defesa candente da democracia, uma vez que Dworkin está firmemente convencido - e acertadamente - que não tem sentido, em um Estado Democrático, que os juízes tenham discricionariedade para decidir os “casos difíceis”.

Mas isso é assim - filosoficamente - porque Dworkin compreendeu devidamente o problema do esquema sujeito-objeto, questão que, entretanto, não está devidamente esclarecida e compreendida pela teoria do direito. Exatamente por superar o esquema sujeito-objeto é que Dworkin não transforma o seu “juiz Hércules” em um juiz solipsista e tampouco em alguém preocupado apenas em elaborar discursos prévios, despreocupados com a aplicação (decisão). Hércules é uma metáfora, demonstrando as possibilidades de se controlar o sujeito da relação de objeto, isto é, com Hércules se quer dizer que não é necessário, para superar o sujeito solipsista da modernidade, substituí-lo por um sistema ou por uma estrutura (v.g., como fazem Luhmann e Habermas). Insista-se: a teoria dworkiniana, assim como a hermenêutica, por serem teorias preocupadas fundamentalmente com a applicatio, não desoneram o aplicador (juiz) dos Begründungsdiskurs (discursos de fundamentação). E isso faz a diferença.

\section{AS CRÍTICAS À HERMENÊUTICA E O PROBLEMA DA} MÁ COMPREENSÃO DO SENTIDO DE "PRÉ-COMPREENSÃO" (VORVERSTÄNDNIS)

Destarte, a discussão que proponho, tanto em Verdade e Consenso como em Hermenêutica Jurídica E(m) Crise, inexoravelmente é atravessada pelas condições de possibilidade da preservação da democracia a partir dos parâmetros do Estado Democrático de Direito. O que sempre pretendi dizer é que não teria sentido que, nesta quadra da história, depois da superação dos autoritarismos/totalitarismos surgidos no século XX e no momento em que alcançamos esse (elevado) patamar de discussão democrática do direito, viéssemos a "depender" da discricionariedade dos juízes na discussão dos assim denominados "casos difíceis" ou em face das (inexoráveis) incertezas da linguagem. Ora, pensar assim seria substituir a democracia pela "vontade do poder” (entendido como o último princípio epocal da modernidade) dos juízes ou de uma doutrina que, seguida pelos juízes, substituísse a produção democrática do direito. Essa produção democrática do direito - plus normativo/qualitativo que caracteriza o Estado Democrático de Direito - é um salto para além do paradigma subjetivista.

É nesse sentido que, ao ser anti-relativista, a hermenêutica funciona como uma blindagem contra interpretações arbitrárias e discricionariedades e/ou decisionismos por parte dos juízes. Veja-se: alguns críticos da hermenêutica - e cito, por todos, o talentoso Daniel Sarmento ${ }^{13}$ - acusam-na de ser irracionalista. E o faz criticando o fato

${ }^{13}$ Cf. Sarmento, Daniel. Interpretação Constitucional, Pré-Compreensão e Capacidades Institucionais do Intérprete. In: Vinte Anos da Constituição Federal de 1988. Claudio Pereira de Souza Neto, Daniel Sarmento e Gustavo Binembojn (org.) Rio de Janeiro: Lumen Juris, 2009, pp. 311 e segs. 
de eu apostar na pré-compreensão como limite ao decisionismo judicial. Para ele, pensar que a pré-compreensão é um limite para a atribuição de sentido, nos moldes que eu proclamo, é um equívoco, "sobretudo diante do fato de que, no quadro de uma sociedade plural e fragmentada como a nossa, coexistem múltiplas visões do mundo disputando espaço”. Sarmento propõe, assim, "não o abandono da pré-compreensão na hermenêutica constitucional - o que não seria possível, em vista da natureza incontornavelmente 'situada' de cada intérprete, nem tampouco desejável, já que a interpretação da Constituição não pode se deslocar completamente da cultura da sociedade em que ela vige - mas a necessidade de submetê-la a uma filtragem, a partir do exercício de uma racionalidade crítica, que tome como premissa a ideia de que todas as pessoas devem ser tratadas como livres e iguais". ${ }^{14}$

À evidência, tenho várias objeções à tese de Sarmento. Antes de tudo, a hermenêutica filosófica (penso que é ela que o autor critica) não pode ser "regionalizada", como, por exemplo, "hermenêutica constitucional" ou "hermenêutica a ser feita em países com 'múltiplas visões de mundo disputando espaço”" (sic). Hermenêutica é filosofia; consequentemente, não há modos diferentes de interpretar, por exemplo, o direito penal, o direito civil, o direito constitucional, o cotidiano, a mídia, etc. Esse é o caráter de universalização da hermenêutica e não de regionalização (se assim se quiser dizer).

No mais, ratifico, aqui, que minhas críticas ao decisionismo, ao discricionarismo, etc., não estão assentadas apenas nisso (a pré-compreensão como limite). Essa é uma das teses (conclusões) de um livro de centenas de páginas. Criticar-me por isso é fazer pouco caso da hermenêutica. Minha aposta na pré-compreensão dá-se em face desta ser condição de possibilidade (é nela que reside o giro-linguistico-ontológico). Minha cruzada contra discricionariedades e decisionismos se assenta no fato de existirem dois vetores de racionalidade (apofântico e hermenêutico), circunstância que o meu crítico não percebe e não entendeu (veja-se, já aqui, a distinção entre compreender e entender, este de nível lógico-argumentativo e aquele de nível hermenêutico-estruturante).

Isso se deve ao fato de que sua crítica provém do âmbito da teoria da argumentação, que (ainda) aposta em “descrições e prescrições”, “subsunções e deduções”, enfim, dos domínios do (metafísico) esquema sujeito-objeto. Mas, registre-se, críticas desse viés já haviam sido feitas à hermenêutica filosófica de há muito, epitetando-a de “relativista”, ataque que Gadamer respondeu com veemência, conforme se pode ver em Wahrheit und Method e na presente obra.

Em definitivo, Sarmento não se dá conta de que o fato de a hermenêutica (filosófica) rechaçar o método não implica ausência (ou carência) de racionalidade. Até porque o método que é destruído pela hermenêutica filosófica é o método acabado e definitivo que o subjetivismo epistemológico da modernidade construiu. $\mathrm{E}$, exatamente porque o método (no sentido moderno da palavra) morreu é que, agora, exige-se maior cuidado no controle da interpretação (atenção: compreender e interpretar são coisas diferentes). Frise-se: o método morreu porque morreu a

\footnotetext{
${ }^{14}$ Idem, ibidem.
} 
subjetividade que sustentava a filosofia da consciência (locus do sujeito solipsista Selbstsüchtiger). Ora, o método soçobra diante da superação do esquema sujeitoobjeto. Método não é sinônimo de racionalidade. Longe disso! E nem é necessário lembrar que a obra Verdade e Método pode (ou deve) ser lida como Verdade contra o Método, o que significa admitir a possibilidade de verdades conteudísticas (não apodídicas, é claro). O que os críticos da hermenêutica - como Daniel Sarmento não entendem é que a hermenêutica atua em um nível de racionalidade I, que é estruturante, transcendental não clássico (Stein); já as teorias da argumentação terreno no qual ele se move - atuam a partir de um vetor de racionalidade de segundo nível, ficando, portanto, no plano lógico e não filosófico (é a contraposição entre o como apofântico [wie] e o como hermenêutico [als]). E, não esqueçamos, filosofia não é lógica.

Eis a distância entre a hermenêutica e teorias procedurais como a teoria da argumentação jurídica. A diferença fundamental talvez esteja no fato de que a hermenêutica atua no âmbito da intersubjetividade (S-S), enquanto as teorias procedurais (como a teoria da argumentação jurídica) não superaram o esquema sujeito-objeto (S-O). É evidente - e compreensível - que qualquer teoria que esteja refém do esquema sujeito-objeto acreditará em metodologias que introduzam discursos adjudicadores no direito (Alexy é um típico caso). Isso explica também por que a ponderação repristina a velha discricionariedade positivista. Isso explica também porque Alexy e seus seguidores - e Sarmento pode ser incluído nesse rol não abrem mão da discricionariedade. Com efeito, a teoria da argumentação não conseguiu fugir do velho problema engendrado pelo subjetivismo: a discricionariedade, circunstância que é reconhecida pelo próprio Alexy: "Os direitos fundamentais não são um objeto passível de ser dividido de uma forma tão refinada que inclua impasses estruturais - ou seja, impasses reais no sopesamento -, de forma a torná-los praticamente sem importância. Neste caso, então, existe uma discricionariedade para sopesar, uma discricionariedade tanto do legislativo quanto do judiciário". ${ }^{15}$

Esse é o ponto que liga a teoria alexyana - e consequentemente, de seus seguidores - ao protagonismo judicial, isto é, o sub-jectum da interpretação termina sendo o juiz e suas escolhas. É também nesse sentido que concordo com Arthur Kaufmann, ao negar qualquer interligação entre hermenêutica e teoria da argumentação jurídica: “A teoria da argumentação provém, essencialmente, da analítica. Esta proveniência pode vislumbrar-se ainda hoje em quase todos os teóricos da argumentação. Não nos é possível, nem necessário, referir todas as correntes da teoria da argumentação, até porque, como nota Ulfrid Neumann, nem sequer existe a teoria da argumentação jurídica. Assim, já é questionável que se possam considerar a tópica e a retórica como formas especiais da teoria da argumentação.” Agregue-se, ademais, diz Kaufmann, que a teoria da argumentação não acompanha a hermenêutica na abolição do esquema sujeito-objeto, prevalecendo-se da objetividade. ${ }^{16}$

${ }^{15}$ Cf. Alexy, Robert. Teoria dos Direitos Fundamentais. Trad. Luis Virgilio A. Silva. São Paulo, Malheiros, 2008, p. 611.

${ }^{16}$ Ver, para tanto, Kaufmann, Arthur. Introdução à Filosofia do Direito e à Teoria do Direito Contemporâneas. Lisboa, Calouste Gulbenkian, 2002, pp. 154 e segs. 
Interessante notar - ainda como resposta à crítica de Sarmento à falta de racionalidade da hermenêutica - que tanto a hermenêutica filosófica como a teoria dworkiniana, cada uma a seu modo, admitem respostas corretas (interpretações corretas). E por que acreditariam nisso, se são irracionais (sic)? Por certo que isso deixa claro que a ideia de racionalidade que guia o talentoso autor em suas críticas é aquela proveniente do método da modernidade, isto é, só pode ser epitetado de "racional" uma teoria que ofereça um método ou um procedimento para sua realização. Mas será que todas as transformações da filosofia desencadeadas no decorrer do século XX permitem ainda afirmar um tal conceito de racionalidade?

Em Dworkin, a integridade e a coerência são o modo de “amarrar” o intérprete, evitando discricionariedades, arbitrariedades e decisionismos (e nem é necessário enfrentar, aqui, as indevidas e injustas críticas feitas à metafórica figura do juiz Hércules, acusado de "solipsismo”). Há algo mais digno do signo da racionalidade que isso? Onde estaria o relativismo hermenêutico? Por certo, se olharmos com cuidado, veremos que relativistas são as teses procedurais, que sustentam uma margem de discricionariedade daquele que manipula o procedimento, como ocorre com a teoria da argumentação. Já na hermenêutica filosófica (gadameriana) a não cisão entre interpretação e aplicação (pensemos nas três subtilitates) e a autoridade da tradição são os componentes que "blindam" a interpretação contra irracionalismos e relativismos. Por isso é que se chama de hermenêutica da faticidade. E por isso também que se pode dizer que os princípios não proporcionam abertura na interpretação, com o que até positivistas como Ferrajoli concordam. O ovo da serpente do irracionalismo, da discricionariedade e do decisionismo está em Kelsen e Hart, cada um ao seu modo. E para quem até hoje acredita que a interpretação é um ato de vontade, basta que se acrescente a esse "ato de vontade" a expressão "de poder" e estaremos de volta ao último princípio epocal da modernidade: a Wille zur Macht, a vontade do poder de Nietsche, que sustenta as diversas formas de pragmatismo no direito, além de concepções realistas como as dos Critical Legal Studies.

Cabe ainda uma observação final acerca da propalada carência de racionalidade na hermenêutica filosófica. Note-se que Sarmento propõe um "quase-abandono" da pré-compreensão, substituindo (ou a controlando) a partir de uma "racionalidade crítica" baseada na "premissa de que todas as pessoas devem ser tratadas como livres e iguais”. Mas como funcionaria essa racionalidade? Quem faria isso? O intérprete/juiz? E de que "lugar" falaria esse intérprete? Do lugar do solipsismo? Lembremos que, ao tratar de uma racionalidade baseada na construção de um auditório universal, sem desigualdades, etc., Habermas ao menos ultrapassou (ess)a razão prática a partir da qual Sarmento parece estar falando. Habermas desonera o juiz dos discursos de fundamentação (Begründungsdiskurs), porque estes já estão previamente dados, restando ao juiz elaborar discursos de aplicação. Ora, tratar a todos de maneira igual não é um nível de racionalidade e tampouco um método; trata-se, sim, de um existencial estruturante do modelo de direito estatuído no e pelo Estado Democrático de Direito (ou, se se quiser, tratar a todos de maneira igual é um critério inegociável no plano dos Begründungsdiskurs). Um direito que não tenha ínsita essa "premissa" é um direito incompatível com esse paradigma. A questão é saber de que modo é 
possível trabalhar com esse "nível de racionalidade” - sic - (tratar a todos de maneira igual) sem depender exatamente da pré-compreensão? O problema, portanto, é que a proposta de racionalidade crítica de Sarmento se desenvolve em um segundo nível de linguagem, isto é, no nível apofântico. Daí a pergunta que a hermenêutica repete indefinidamente: de que modo um processo lógico-argumentativo pode "acontecer" sem a pré-compreensão (atenção: pré-compreensão e não "preconceitos”)? Eis o “enigma” proposto por Schnädelbach, na esteira de Heidegger e Gadamer: o problema do sentido se situa antes do problema do conhecimento.

Esta é uma questão que sequer chega a ser percebida pelos críticos da hermenêutica e que Sarmento também não a menciona em seu texto. Isto porque, como as teorias da argumentação estão fortemente atreladas à tradição da filosofia analítica, há uma espécie de tendência em colocar o enunciado como ponto de partida para o problema da linguagem e, consequentemente, para a resolução dos problemas (lógicos) que povoam o universo jurídico. Ressalte-se que esta tendência está sedimentada no senso comum teórico que atravessa o direito brasileiro desde há muito tempo.

Com efeito, já na primeira edição de Hermenêutica Jurídica (e)m Crise, demonstro, de modo contundente, o fato de a dogmática jurídica ainda buscar capturar, na interpretação da lei, a essência das palavras. Ou seja, para grande parcela do pensamento jurídico pátrio, o problema da interpretação da lei estaria resolvido se fosse possível construir um grande dicionário onde estivesse contida toda a essência significativa transmitida pelas palavras. Não deixa de ser sintomático que o livro esteja hoje em sua oitava edição e a crítica permaneça terrivelmente atual. E também a teoria da argumentação de Sarmento permanece no interior daqueles que entendem que o problema da compreensão e da justeza dos enunciados começa com as palavras e a essência que delas brotam.

Nesse ponto não é demais registrar que foi Heidegger quem mostrou que, em filosofia, é equivocado pensar nas palavras como fonte de "essências de significado". Em outras palavras, Heidegger criticava abertamente a existência de uma "filosofia da linguagem” porque esta desconsiderava o lugar mais originário de onde a questão da linguagem exsurge. Nessa medida, depois de demonstrar como o enunciado é um modo derivado da interpretação (que por sua vez foi possibilitada por uma [pré] compreensão existencial), aparece a seguinte afirmação no parágrafo 34 de Ser $e$ Tempo: das significações brotam palavras; estas, porém, não são coisas dotadas de significados. Note-se: não é nas palavras que devemos buscar os significados do mundo (ou do direito, para ser mais específico), mas é para significar (o direito) que necessitamos de palavras. É para isso que as palavras servem: para dar significado às coisas! Para haver compreensão, basta que a articulação do significado dado às coisas (ou ao Direito) esteja provido de sentido. Isto significa dizer: o Dasein, em seu modo prático de ser-no-mundo, desde sempre já se move - compreensivamente - em um todo de significados - que em Ser e Tempo recebe o nome de significância - e é desta relação fática de compreensão afetivamente disposta que brotam as significações das palavras. Dito de outro modo: articulamos as palavras que temos disponíveis projetando sentidos a partir deste todo de significados. Ou seja, o discurso - que é o modo 
de manifestação da linguagem - é articulado sempre imerso nesta dimensão de (pré)compreensibilidade da significância.

Esse é o significado da pré-compreensão. Ela não é uma criação da hermenêutica filosófica de Gadamer. Ao contrário, o próprio Gadamer admite em Verdade e Método que a pré-compreensão - tese fundamental para construção de sua filosofia - é uma descoberta heideggeriana. E é em Heidegger que está o mais eficaz remédio contra o relativismo. Afinal, Ser e Tempo é um livro antirelativista. Numa época de pessimismos (social, econômico e filosófico), em que não faltavam teses que interpretavam o mundo no sentido do juízo final e do recomeço radical - lembro aqui de A Queda do Ocidente, de Oswald Spengler -, Ser e Tempo postula a verdade como dimensão em que o ser-aí (Dasein) desde sempre se movimenta. Nessa medida, a questão da significância, da estrutura prévia do enunciado e da constituição existencial (prévia) da compreensão são as questões nucleares para a correta introdução ao problema da pré-compreensão e sua relação com a verdade.

Que fique bem claro: não se pode confundir pré-compreensão com visão de mundo, preconceitos ou qualquer outro termo que revele uma abertura para o relativismo. A pré-compreensão demonstra exatamente que não há espaço para este tipo de relativização subjetivista que acabaria, no fundo, caindo nas armadilhas de um ceticismo filosófico.

De todo modo, o que transparece das - duras, porém elegantes - críticas de Sarmento é exatamente a confusão entre pré-compreensão e preconceitos. Ora, como demonstrado acima, a pré-compreensão é do nível do a priori, antecipador de sentido. A pré-compreensão é uma espécie de totalidade que não pode ser fatiada (como se existisse uma pré-compreensão religiosa e outra leiga/laica). Não nos perguntamos por que compreendemos, pela simples razão de que já compreendemos lembrando aquilo que ensina Heidegger: em todo Discurso, enquanto um existencial do ser-aí, já há uma compreensibilidade sendo articulada. É por isso que Gadamer diz que o método chega tarde. A pré-compreensão não significa uma estrutura de caráter histórico e cultural que carateriza uma posição que se prende a um conteúdo determinado que possa ser apresentado como válido contra outro conteúdo. O que está em questão aqui é o problema do preconceito, que pode aparecer na ideologia, na visão de mundo e nos conflitos de caráter histórico. ${ }^{17}$ Daí a lição de Heidegger (do qual - frise-se uma vez mais - se originou a hermenêutica filosófica de Gadamer) acerca da estrutura da compreensão: embora possa ser tolerado, o círculo hermenêutico não deve ser rebaixado/degradado a círculo vicioso. Ele esconde uma possibilidade positiva do conhecimento mais originário, que, evidentemente, somente será compreendida de modo adequado quando ficar claro que a tarefa primordial, constante e definitiva

\footnotetext{
${ }^{17}$ Para evitar esse tipo de mal-entendido, nada melhor do que lembrar o próprio Gadamer (Verdade e Método. Traços Fundamentais de Uma Hermenêutica Filosófica., op.cit.), para quem os preconceitos e opiniões prévias (e fica claro que é disso que Sarmento está falando e não da Vorvertändnis) que ocupam a consciência do intérprete não se encontram à sua livre disposição. Por isso o intérprete não está em condições de distinguir por si mesmo e de antemão os preconceitos produtivos, que tornam possível a compreensão, daqueles outros (aqui está o ponto fulcral da confusão entre pré-compreensão e preconceitos) que a obstaculizam e que levam a equívocos.
} 
da interpretação continua sendo não permitir que a posição prévia (Vorhabe), a visão prévia (Vorsicht) e a concepção prévia (Vorbegriff) lhe sejam impostas por intuições ou noções populares (do senso comum). ${ }^{18}$

É a esses preconceitos que, por certo, Sarmento se refere. Por isso seu alvo é equivocado. Atira nos preconceitos buscando atingir a pré-compreensão (reitero que sempre estou falando a partir da pré-compreensão hermenêutico-filosófica e que é o objetivo da crítica de Sarmento). Isso não quer dizer que qualquer tipo de pensamento possa se apresentar como depurado dos elementos ideológicos-valorativos. Para diminuí-los (controlá-los), podemos apresentar justamente, por exemplo, a ideia de uma crítica das ideologias, dos valores, etc. ${ }^{19}$ É por intermédio dessa crítica que se pretendem romper certas barreiras para o diálogo e discussões. Numa palavra: Sarmento talvez tenha sido traído pelos preconceitos e não pela pré-compreensão.

\section{AINDA O MESMO PROBLEMA, AGORA SOB OUTRA PERSPECTIVA}

O tema é, pois, recorrente, valendo lembrar que essa crítica à falta/ausência de racionalidade é feita também por Inocêncio Mártires Coelho, que, entretanto, confunde a hermenêutica filosófica com o "método hermenêutico-concretizador" (faz uma crítica a este, mas atinge àquela - e por isso merece ser discutida). Inicia dizendo que esse "método hermenêutico-concretizador" é pouco diferente do método tópicoproblemático (o que, por si, já constitui um problema, embora sem maior relevância para os objetivos da presente anotação). Mais ainda, assinala que os adeptos do método hermenêutico-concretizador "procuram ancorar a interpretação no próprio texto constitucional - como limite da concretização -, mas sem perder de vista a realidade que intenta regular e que, afinal, lhe esclarece o sentido; noutras palavras, trata-se de uma postura que encontra apoio, dentre outras, nas seguintes descobertas hermenêuticas de Gadamer: interpretar sempre foi, também, aplicar; aplicar o direito significa pensar, conjuntamente, o caso e a lei, de tal maneira que o direito propriamente dito se concretize; e, afinal, o sentido de algo geral, de uma norma, por exemplo, só pode ser justificado e determinado, realmente na concretização e através dela”.

Na sequência - pressupondo como fato consumado a "origem comum” do método hermenêutico-concretizador e da hermenêutica filosófica - Mártires Coelho investe contra a categoria da pré-compreensão, verbis: "Considerando, entretanto, que toda pré-compreensão, em certa medida, possui algo de irracional, pode-se dizer que, apesar dos seus esforços, os que propugnam por esse método (sic), assim como

\footnotetext{
${ }^{18}$ Como bem assinala Gadamer (Verdade e Método. Traços Fundamentais de Uma Hermenêutica Filosófica, op. cit,), o que Heidegger diz aqui não é em primeiro lugar uma exigência à práxis da compreensão, mas descreve a forma de realização da própria interpretação compreensiva. A reflexão hermenêutica de Heidegger tem o seu ponto alto não no fato de demonstrar que aqui prejaz um círculo, mas que este círculo tem um sentido ontológico positivo. A descrição como tal será evidente para qualquer intérprete que saiba o que faz. Toda interpretação correta tem que proteger-se da arbitrariedade de intuições repentinas, enfim, dos preconceitos e voltar seu olhar para as "coisas elas mesmas" (veja-se que textos sempre tratam de coisas, sendo que, por isso, texto é sempre um evento). Por isso, diz Gadamer, a compreensão somente alcança sua verdadeira possibilidade quando as opiniões prévias com as quais inicia não forem arbitrárias.

19 Sarmento não se dá conta de que, para Gadamer, a antecipação de sentido, que guia a nossa compreensão, não é um ato da subjetividade, já que se determina a partir da comunhão que nos une com a tradição. Esse equívoco decorre do lugar de onde fala o meu crítico: o esquema sujeito-objeto.
} 
os defensores do processo tópico-problemático, ficam a dever aos seus críticos algum critério de verdade que lhes avalize as interpretações, de nada valendo, para quitar essa dívida, apelarem para uma imprecisa e mal definida verdade hermenêutica, que pode ser muito atraente como ideia, mas pouco nos diz sobre os alicerces dessa construção". 20

Coloquemos, então, as discordâncias com o autor: em primeiro lugar, o método hermenêutico-concretizador é trazido por Canotilho a partir de duas fontes: Hesse e Müller, não fazendo nenhuma referência a Gadamer. De fato, há, em Müller (que é associado ao método estruturante), uma base gadameriana. A questão, no entanto, não é a influência de Gadamer em Müller ou Hesse, mas o modo como Gadamer é lido pelos juristas. Müller, por exemplo, usa Gadamer para justificar a relação da interpretação com a aplicação e, ao mesmo tempo, procura oferecer uma estrutura metodológica para controlar a interpretação. Não podemos esquecer da relação do pensamento de Gadamer com os métodos constitutivos da compreensão! Em Gadamer, não é possível associar métodos e a antecipação da compreensão na circularidade hermenêutica. Isso de modo algum! Na sequência, tal como já fizera Daniel Sarmento, Mártires Coelho confunde pré-compreensão com preconceitos, ou seja, utiliza pré-compreensão como se fosse preconceito, ideologia, subjetividades ou visão de mundo. Realiza, portanto, um processo de “fatiamento” da pré-compreensão.

Insisto: a pré-compreensão é uma espécie de todo que sempre nos antecipa quando nos relacionamos com os entes no mundo. Em hipótese alguma isso representa uma ideia, mas, pelo contrário, isso é possibilitado por um ver fenomenológico que acessou o mundo prático em suas estruturas mais originárias. Isso implica a seguinte pergunta: por que a pré-compreensão de que fala Gadamer - que, insista-se, é estruturante, que antecipa o sentido (novamente a razão hermenêutica de que fala Ernst Schnädelbach) - seria irracional? Por que a hermenêutica não oferece nenhum critério "garantidor" da verdade? Novamente, o que está em jogo é uma ideia de que o racional só é alcançado quando se tem um método disponível para assegurar a organização e o processamento do processo de conhecimento do direito.

Mas, observemos: o ataque de Mártires Coelho não é - diretamente - à hermenêutica filosófica. Mas tudo indica que a confusão entre hermenêutica e método concretizador acabou por propiciar uma cobrança de "racionalidade" da hermenêutica, uma vez que o professor brasiliense diz de nada valer, "para quitar essa dívida, apelarem para uma imprecisa e mal definida verdade hermenêutica". Aqui transparece, nitidamente, que o lugar da crítica de Mártires Coelho não é o ontological turn e, sim, o da filosofia da consciência, enfim, do lugar da fala do método tradicional da modernidade. Gadamer, como tenho insistido, faz uma ruptura com o método a partir da superação do esquema sujeito-objeto, confrontando-se, abertamente, com o sujeito solipsista (Selbstsüchtiger) da modernidade. Mas confundir essa ruptura com o método com a instauração de uma irracionalidade (ou um livre atribuir de sentidos) é confundir, também neste ponto, os níveis em que se dão a compreensão e a explicitação dessa compreensão.

${ }^{20}$ Cf. Mártires Coelho, Inocêncio. Interpretação Constitucional. Porto Alegre: Fabris, 1992, p. 103-104. 
Ora, Mártires Coelho cobra da hermenêutica uma razão instrumental que a hermenêutica afastou justamente em face do esquema sujeito-objeto. Mas é preciso compreender que, no lugar disso, Gadamer coloca a autoridade da tradição, a aferição da verdade hermenêutica a partir dos pré-juízos legítimos e ilegítimos, circunstância que reforça a relação da hermenêutica para com o direito, mormente pelo locus privilegiado representado pela Constituição. Não esqueçamos - novamente - da applicatio gadameriana e sua incindibilidade para com a interpretação. Essa circunstância favorece em Dworkin a utilização da integridade e da coerência como modos de controlar/amarrar o intérprete, evitando discricionariedades e arbitrariedades, problemática que perpassa este artigo. E, não esqueçamos, numa palavra, o que Gadamer dizia acerca da acusação de irracionalidade e/ou de relativismo à hermenêutica: o relativismo não deve ser combatido; deve ser destruído. Parece claro isso: o irracionalismo é, paradoxalmente, produto da "racionalidade instrumental" da modernidade!

Por fim, importa referir que essas críticas - embora relevantes e feitas de forma sofisticada por autores do porte do professor da UNB e do IDP - tornam-se problemáticas porque se originam de um território ocupado pelo proceduralismo das teorias argumentativas. Ainda, numa palavra: com Habermas e Luhmann, podemos, ao menos, discutir uma alternativa para o pensamento pós-metafísico (Habermas) e, até mesmo, as possibilidades de qualquer uma dessas alternativas (Luhmann). Lembremos que Habermas é anti-relativista, anti-discricionarista, assim como Dworkin. Com certeza, Luhmann não compactua com irracionalidades (pode-se dizer que, nele, as contingências são evitadas pelas estruturas). O que não é possível é avaliar o pensamento hermenêutico-gadameriano-dworkiniano pela lente da filosofia da consciência (portanto, pela metafísica moderna).

Por tudo isso - e permito-me insistir nesse ponto - discutir as condições de possibilidade da decisão jurídica é, antes de tudo, uma questão de democracia. Por isso, deveria ser despiciendo acentuar ou lembrar que a crítica à discricionariedade judicial não é uma "proibição de interpretar". Ora, interpretar é dar sentido (Sinngebung). É fundir horizontes. E direito é um sistema de regras e princípios, “comandado” por uma Constituição. Assim, afirmar que as palavras da lei (lato sensu) contêm vaguezas e ambiguidades e que os princípios podem ser - e na maior parte das vezes são mais “abertos” em termos de possibilidades de significado, não constitui novidade.

O que deve ser entendido é que a realização/concretização desses textos (isto é, a sua transformação em normas) não depende de uma subjetividade assujeitadora (esquema sujeito-objeto), como se os sentidos a serem atribuídos fossem fruto da vontade do intérprete, dando assim razão a Kelsen, para quem a interpretação a ser feita pelos juízos é um ato de vontade (sic). Isso para dizer o mínimo!

Nessa mesma linha, é possível dizer que também Eduardo Appio não entendeu a tese que proponho para combater o problema da discricionariedade no direito. Com efeito, em trabalho recente o autor apresenta críticas a pontos específicos de minha obra, catalogando-a - em título específico de seu texto - sob o rótulo de “interpretativismo hermenêutico de Lenio Streck". ${ }^{21}$

${ }^{21}$ Cf. Appio, Eduardo. Direitos das Minorias. São Paulo: Revista dos Tribunais, 2009, pp. 297-299. 
De plano, um problema se apresenta. Parece-me claro que há uma articulação equivocada do conceito de interpretativismo. Como é cediço, interpretativistas são as posturas teóricas que defendem uma interpretação originalista da Constituição. $\mathrm{Na}$ medida em que tais teorias surgem nos Estados Unidos, trata-se de um originalismo com relação à Constituição Norte-americana. Sendo mais claro, há uma disputa histórica entre os teóricos norte-americanos - pelo menos desde o clássico artigo de Thomas Grey que, pela primeira vez, estabeleceu e classificou desse modo a diferença metodológica em relação à interpretação da Constituição ${ }^{22}$ - sobre como deve ser encarada, metodicamente, a interpretação da Constituição. Segundo Grey, duas são as posições que se contrapõem: o interpretativismo e o não-interpretativismo. O interpretativismo relaciona-se à postura origininalista que os limites de liberdade de conformação do legislador devem se dar nos limites do texto escrito; ou seja, basta a grafia constitucional para que os limites ao processo político sejam determinados e instaurados. Já as posturas não-interpretativistas postulam uma espécie de política constitucional, aproximando-se das ideias defendidas pelo realismo jurídico.

Ora, por certo que, ao defender a possibilidade e a necessidade de respostas corretas em direito (ou, na fórmula que proponho: respostas adequadas constitucionalmente), não é possível ter-me como um interpretativista (originalista). Isso por um motivo simples: quando afirmo tal tese, tenho por pressuposto que a dicotomia interpretacionismo - não-interpretacionismo está - de há muito superada e os problemas daí decorrentes já tenham sido sanados. Isto porque, quando em Law's Empire Dworkin enfrenta o aguilhão semântico e o problema do pragmatismo, há uma inevitável superação das teses clássicas sobre a interpretação da Constituição Americana. Ou seja, o problema da resposta correta não se resume à identificação da sentença judicial com o texto da lei ou da Constituição. Se pensássemos assim, estaríamos ainda presos aos dilemas das posturas semânticas. Quando se fala em resposta correta, há uma série de acontecimentos que atravessam o direito que ultrapassam o mero problema da "literalidade do texto".

Daí a confusão operada por Appio: para ele, quando assevero que os limites semânticos do texto devem ser respeitados, como no caso do problema envolvendo o casamento de pessoas do mesmo sexo, conclui de minha abordagem um inexplicável viés de contenção judicial em benefício de uma estrita exegese, de acordo com a literalidade da norma. Ainda no âmbito da série de equívocos e confusões feitas pelo autor no decorrer do texto, veja-se a equivocada afirmação no sentido de que a hermenêutica filosófica "não aponta um caminho a ser seguido, pois apenas recomenda que o intérprete deve deixar a interpretação fluir naturalmente”, como se eu estivesse a propor uma modalidade de laissez faire hermenêutico. É preciso insistir: a hermenêutica por mim trabalhada é antirelativista e antidiscricionária, o que significa dizer que o sentido não está à disposição do intérprete (o que é diferente de dizer que há uma “exegese de estrita literalidade”).

${ }^{22}$ Cf. Grey, Thomas C. “Do We Have un Unwritten Constitution?” In: Stanford Law Review n. 27, 1975, pp. 703 e segs. 
Na verdade, o "drama" da discricionariedade que venho criticando de há muito é que esta transforma os juízes em legisladores. $\mathrm{E}$ mais do que transformar os juízes em legisladores, o "poder discricionário" propicia a "criação" do próprio objeto de "conhecimento", típica problemática que remete a questão ao solipsismo característico da filosofia da consciência no seu mais exacerbado grau. Ou seja, concebe-se a razão humana como "fonte iluminadora" do significado de tudo o que pode ser enunciado sobre a realidade. Nesse paradigma, as coisas são reduzidas aos nossos conceitos e às nossas concepções de mundo, ficando à dis-posição de um protagonista (no caso, o juiz, enfim, o Poder Judiciário). E isso acarreta consequências graves no Estado Democrático de Direito.

Eis a complexidade: historicamente, os juízes eram acusados de ser a boca da lei. Essa crítica decorria da cisão entre questão de fato e questão de direito, isto é, a separação entre faticidade e validade (problemática que atravessa os séculos). As diversas teorias críticas sempre aponta(ra)m para a necessidade de rompimento com esse imaginário exegético (ainda hoje cenário de "descobertas" no plano do senso comum teórico dos juristas). Ocorre que, ao mesmo tempo, a crítica do direito, em sua grande maioria, sempre admitiu - e cada vez admite mais um alto grau de discricionariedade nos casos difíceis, nas incertezas designativas, enfim, na zona de "penumbra" das leis. Tudo isso tem consequências sérias para o direito. Seríssimas.

\section{6. À GUISA DE CONSIDERAÇÕES FINAIS}

Quando questiono os limites da interpretação - a ponto de alçar a necessidade desse controle à categoria de princípio basilar da hermenêutica jurídica está obviamente implícita a rejeição da negligência do positivismo "legalista" para com o papel do juiz, assim como também a "descoberta" das diversas correntes realistas e pragmatistas que se coloca(ram) como antítese ao exegetismo das primeiras. Ou seja, a questão que está em jogo ultrapassa de longe essa antiga contraposição de posturas, mormente porque, no entremeio destas, surgiram várias teses, as quais, sob pretexto da superação de um positivismo fundado no sistema de regras, construíram um modelo interpretativo calcado em procedimentos, cuja função é(ra) descobrir os valores presentes (implícita ou explicitamente) no novo direito, agora "eivado de princípios e com textura aberta”.

Já as posturas subjetivistas, especialmente, redundaram em um fortalecimento do protagonismo judicial, fragilizando sobremodo o papel da doutrina. Em terrae brasilis essa problemática é facilmente notada no impressionante crescimento de uma cultura jurídica cuja função é reproduzir as decisões tribunalícias. É o império dos enunciados assertóricos que se sobrepõe à reflexão doutrinária. Assim, os reflexos de uma aposta no protagonismo judicial não demorariam a ser sentidos: a doutrina se contenta com "migalhas significativas" ou "restos dos sentidos previamente produzidos pelos tribunais". Com isso, a velha jurisprudência dos conceitos acaba chegando ao direito contemporâneo a partir do lugar que era o seu destinatário: as decisões judiciais - são elas, agora, que produzem a conceitualização. Com uma agravante: o sacrifício da faticidade; o esquecimento do mundo prático. 
De todo modo, o ponto fulcral não está nem no exegetismo, nem no positivismo fático (por todos, basta examinar as teses do realismo jurídico nas suas variadas perspectivas) e tampouco nas teorias que apostam na argumentação jurídica como um passo para além da retórica e como um modo de "corrigir as insuficiências do direito legislado”. Na verdade, o problema, em qualquer das teses que procuram resolver a questão de como se interpreta e como se aplica, localiza-se no sujeito da modernidade, isto é, no sujeito “da subjetividade assujeitadora”, objeto da ruptura ocorrida no campo da filosofia pelo giro linguístico-ontológico e que não foi recepcionado pelo direito.

Isso significa poder afirmar que qualquer fórmula hermenêutico-interpretativa que continue a apostar no solipsismo estará fadada a depender de um sujeito individualista (ou egoísta, para usar a melhor tradução da palavra em alemão Selbstsüchtiger), como que a repristinar o nascedouro do positivismo através do nominalismo. Está-se lidando, pois, com rupturas paradigmáticas e princípios epocais que fundamentam o conhecimento em distintos períodos da história (do eidos platônico ao último princípio fundante da metafísica moderna: a vontade do poder, de Nietzsche).

Em síntese - e quero deixar isso bem claro - para superar o positivismo é preciso superar também aquilo que o sustenta: o primado epistemológico do sujeito (da subjetividade assujeitadora) e o solipsismo teórico da filosofia da consciência. Não há como escapar disso. E penso que apenas com a superação dessas teorias que ainda apostam no esquema sujeito-objeto é que poderemos sair dessa armadilha que é o solipsismo. A hermenêutica se apresenta nesse contexto como um espaço no qual se pode pensar adequadamente uma teoria da decisão judicial, livre que está tanto das amarras desse sujeito onde reside a razão prática como daquelas posturas que buscam substituir esse sujeito por estruturas ou sistemas. Nisso talvez resida a chave de toda a problemática relativa ao enfrentamento do positivismo e de suas condições de possibilidade.

É tarefa contínua, pois, que se continue a mostrar como persistem equívocos nas construções epistêmicas atuais e como tais equívocos se dão em virtude do uso aleatório das posições dos vários autores que compõe o chamado pós-positivismo. Com efeito, isso fica evidente no conceito de princípio. O caráter normativo dos princípios - que é reivindicado no horizonte das teorias pós-positivistas - não pode ser encarado como um álibi para a discricionariedade, pois, desse modo, estaríamos voltando para o grande problema não resolvido pelo positivismo.

Com isso quero dizer que a tese da abertura (semântica) dos princípios - com que trabalha a teoria da argumentação (e outras teorias sem filiação a matrizes teóricas definidas) - é incompatível com o modelo pós-positivista de teoria do direito. Na verdade, o positivismo sempre nutriu uma espécie de aversão aos princípios. Na medida em que na discussão sobre os princípios sempre nos movemos no território precário da razão prática, o positivismo - de todos os matizes trata(va)-o sempre como uma espécie de reforço que possuía no máximo uma função de integração sistemática. Esse é o significado da doutrina dos princípios ocultos de que fala Esser, ou seja, uma tentativa de sanar uma possível incompletude sistemática no todo do ordenamento jurídico. 
Nessa medida, é preciso ressaltar que só pode ser chamada de pós-positivista uma teoria do direito que tenha, efetivamente, superado o positivismo. Parece óbvio reforçar isso. A superação do positivismo implica enfrentamento do problema da discricionariedade judicial ou, também poderíamos falar, no enfrentamento do solipsismo da razão prática. Implica, também, assumir uma tese de descontinuidade com relação ao conceito de princípio. Ou seja, no pós-positivismo, os princípios não podem mais serem tratados no sentido dos velhos princípios gerais do direito nem como cláusulas de abertura.

De efetivo, uma teoria pós-positivista necessita superar os três elementos fundantes dos diversos positivismos jurídicos:

Primeiro, porque o positivismo sempre se caracterizou pelas fontes sociais do direito, pela separação entre direito e moral e pela discricionariedade delegada ao juiz nos hard cases ou nas incertezas da linguagem em geral.

Segundo, porque, como já demonstrado alhures, há uma correspondência de tais características com os obstáculos opostos pelo positivismo ao novo constitucionalismo (neoconstitucionalismo): a falta de uma nova teoria das fontes, a falta de uma nova teoria da norma e a ausência de uma teoria da interpretação que dê conta da superação do paradigma objetivista aritotélico-tomista e da filosofia da linguagem. Há, assim, um modo de unificar esses características e os obstáculos, uma vez que é possível vislumbrar uma imbricação ou cruzamento entre eles.

A partir disso, a elaboração de uma teoria pós-positivista tem que levar em conta os seguintes elementos:

I. Há que se ter presente que o direito do Estado Democrático de Direito supera a noção de "fontes sociais", em face daquilo que podemos chamar de prospectividade, isto é, o direito não vem a reboque dos "fatos sociais" e, sim, aponta para a reconstrução da sociedade. Isso é facilmente detectável nos textos constitucionais, como em terrae brasilis, onde a Constituição estabelece que o Brasil é uma República que visa a erradicar a pobreza, etc, além de uma gama de preceitos que estabelecem as possibilidades (e determinações) do resgate das promessas incumpridas da modernidade.

II. Essa problemática tem relação direta com a construção de uma nova teoria das fontes, uma vez que a Constituição será o locus da construção do direito dessa nova fase do Estado (Democrático de Direito). Consequentemente, não mais há que se falar em qualquer possibilidade de normas jurídicas que contrariem a Constituição e que possam continuar válidas; mais do que isso, muda a noção de parametricidade, na medida em que a Constituição pode ser aplicada sem a interpositio legislatoris, fonte de serôdias teorias que relativizavam a validade/eficácia das normas.

III. Não pode restar dúvida de que tanto a separação como a dependência/ vinculação entre direito e moral estão ultrapassadas, em face daquilo que se convencionou chamar de institucionalização da moral no direito (esta é uma fundamental contribuição de Habermas para o direito: a co-originariedade entre direito e moral), circunstância que reforça, sobremodo, a autonomia do direito. Isto porque a moral regula o comportamento interno das pessoas, só que esta “regulação” não tem 
força jurídico-normativa. O que tem força vinculativa, cogente, é o direito, que recebe conteúdos morais (apenas) quando de sua elaboração legislativa ${ }^{23}$. Observemos: é por isso que o Estado Democrático de Direito não admite discricionariedade (nem) para o legislador, porque ele está vinculado a Constituição (lembremos sempre a ruptura paradigmática que representou o constitucionalismo compromissório e social). O “constituir” da Constituição é a obrigação suprema do direito. É, pois, a virtude soberana (parafraseando Dworkin). A partir da feitura da lei, a decisão judicial passa a ser racionalizada na lei, que quer dizer, "sob o comando da Constituição" e não "sob o comando das injunções pessoais-morais-políticas do juiz ou dos tribunais”. Essa questão é de suma importância, na medida em que, ao não mais se admitir a tese da separação (e tampouco da vinculação), não mais se corre o risco de colocar a moral como corretiva do direito. E isso terá consequências enormes da discussão “regra-princípio”.

IV. Na sequência e em complemento, tem-se que essa cisão entre direito e moral coloca(va) a teoria da norma à reboque de uma tese de continuidade entre os velhos

\footnotetext{
${ }^{23}$ Aqui cabe um esclarecimento, para novamente evitar mal entendidos. A elaboração legislativa não esgota - nem de longe - o problema do conteúdo do direito. Quando concordamos que as questões morais, políticas, etc, façam parte da "tarefa legislativa”, isso não quer dizer que haja, de minha parte - e, por certo, dos adeptos das posições substancialistas - uma viravolta na questão "procedimentalismo-substancialismo". Se as posturas procedimentalistas pretendem esgotar essa discussão a partir da garantia do processo democrático de formação das leis, isso, no entanto, não esgota a discussão da concreta normatividade, locus do sentido hermenêutico do direito. De fato, mais do que apostar na formulação democrática do direito, há que se fazer uma aposta paradigmática, isto é, acreditar na perpestiva pós-positivista do novo constitucionalismo e sua materialidade principiológica. A virtude soberana não se dá simplesmente na formulação legislativa e na "vontade geral”. Fundamentalmente, ela será encontrada na Constituição, que estabeleceu uma ruptura com a discricionariedade política que sempre sustentou o positivismo. E tudo isso está ancorado no contramajoritarismo, que vai além do mero controle da aferição da correção dos procedimentos democráticos utilizados na feitura das leis. Também é na Constituição que encontraremos os mecanismos de controle da aferição substancial dos textos legislados e da aplicação destes textos (nunca esqueçamos: o substancialismo não abre mão do procedimentalismo). A igualdade, o devido processo legal, o sentido do republicanismo, a perspectiva de Estado Social, a obrigação de concretização dos direitos fundamentais-sociais, para citar apenas estes componentes paradigmáticos, são obrigações principiológicas de raiz, que vinculam a applicatio. E os componentes a serem utilizados na discussão da aplicação do direito somente poderão exsurgir desse paradigma constitucional. Legislação democraticamente produzida - e válida - significa "sentido filtrado principiologicamente”. O combate que aqui se trava - de cariz anti-discricionário - tem a objetivo de preservar esse grau acentuado de autonomia que o direito adquiriu com a fórmula das Constituições compromissórias (e dirigentes). Portanto, não será um posicionamento ad hoc, fruto de apreciações advindas de uma moral individual ou convicções políticas, etc (em síntese, argumentos de política), que "valerá” mais do que esse "produto democrático", o qual e é desnecessário frisar isso - deverá sempre passar pelo controle paramétrico-constitucional. Como já referido: a hermenêutica não abre mão do sujeito da relação, enfim, do sujeito que lida com objetos. O que ela supera é o esquema sujeito-objeto, responsável pelo sujeito solipsista que sustenta as posturas subjetivistas-axiologistas da maioria das teorias do direito mesmo no século XXI. Na hermenêutica há um efetivo controle da interpretação a partir da tradição (da autoridade desta), da obrigação da integridade, da coerência, da igualdade, da isonomia, enfim, da incorporação dos princípios constitucionais que podemos chamar aqui de virtudes soberanas em homenagem à Dworkin. Por isso, os discursos "predadores" do direito são rechaçados por essa "blindagem hermenêutica" que protege o direito produzido democraticamente. E é exatamente por isso que é possível sustentar respostas adequadas a Constituição, portanto, apostar em uma teoria da decisão e não apenas em uma teoria da legislação. Múltiplas respostas dizem respeito ao relativismo, e, estas, estão umbilicalmente relacionadas com o positivismo.
} 
princípios gerais e os (novos) princípios constitucionais. Sustentado no paradigma do Estado Democrático Constitucional, o direito, para não ser solapado pela economia, pela política e pela moral (para ficar apenas nessas três dimensões predatórias da autonomia do direito), adquire uma autonomia que, antes de tudo, funciona como uma blindagem contra as próprias dimensões que o engendra(ra)m.

V. Tudo isso significa assumir que os princípios constitucionais - e a Constituição lato sensu (afinal, qualquer prospecção hermenêutica que se faça - seja a partir de Dworkin, Gadamer ou Habermas - só tem sentido no contexto do paradigma do Estado Democrático de Direito) - ao contrário do que se possa pensar, não remete para uma limitação do direito (e de seu grau de autonomia), e, sim, para o fortalecimento de sua de autonomia.

VI. Consequentemente, nos casos assim denominados de "difíceis”, não é mais possível "delegar” para o juiz a sua resolução. Isto porque não podemos mais aceitar que, em pleno Estado Democrático de Direito, ainda se postule que a luz para determinação do direito in concreto provenha do protagonista da sentença ${ }^{24}$. Isso significa que, para além da cisão estrutural entre casos simples e casos difíceis, não pode haver decisão judicial que não seja fundamentada e justificada em um todo coerente de princípios que repercutam a história institucional do direito. Desse modo, tem-se por superada a discricionariedade a partir do dever fundamental de resposta correta que recai sobre o juiz no contexto do paradigma do Estado Democrático de Direito.

Por tudo isso, torna-se necessário construirmos as condições para a elaboração de uma teoria da decisão jurídica, ou seja, no plano da validade, discutirmos as possibilidades (ou necessidades) de elaborarmos um efetivo controle das decisões judiciais. Uma democracia não se consolida com delegações em favor do Poder Judiciário. O direito não é aquilo que os Tribunais dizem que é. Se isso fosse verdadeiro, a doutrina não teria importância. E, na medida em que uma República de Juízes é impossível, alguns não o serão. Consequentemente, devemos pensar no espaço da democracia daqueles que não são juízes (que, como se sabe, são milhões de brasileiros). Este é o desafio de uma teoria crítica do direito nesta quadra da história.

\footnotetext{
24 Do mesmo modo, a ideia de imparcialidade pura do juiz ou o uso de estratégias argumentativas para isentar a responsabilidade do julgador no momento decisório podem levar à introdução de argumentos de política na decisão jurídica. Nesse sentido são precisas as afirmações de Dworkin: "A política constitucional tem sido atrapalhada e corrompida pela idéia falsa de que os juízes (se não fossem tão sedentos de poder) poderiam usar estratégias de interpretação constitucional politicamente neutras. Os juízes que fazem eco a essa idéia falsa procuram ocultar até de si próprios a inevitável influência de suas próprias convicções, e o que resulta daí é uma suntuosa mendacidade. Os motives reais das decisões ficam ocultos tanto de uma legítima inspeção pública quanto de um utilíssimo debate público. Já a leitura moral prega uma coisa diferente. Ela explica porque a fidelidade à Constituição e ao direito exige que os juízes façam juízos atuais de moralidade política e encoraja assim a franca demonstração das verdadeiras bases destes juízos, na esperança de que os juízes elaborem argumentos mais sinceros, fundados em princípios, que permitam ao público participar da discussão" (Direito de Liberdade. Leitura Moral da Constituição Americana. São Paulo: Martins Fontes, 2006, p. 57).
} 


\section{REFERÊNCIAS BIBLIOGRÁFICAS}

ALEXY, Robert. Teoria dos Direitos Fundamentais. Trad. Luis Virgilio A. Silva. São Paulo: Malheiros, 2008.

APPIO, Eduardo. Direitos das Minorias. São Paulo: Revista dos Tribunais, 2009.

DWORKIN, Ronald. Levando os Direitos a Sério. Tradução de Nelson Boeira. São Paulo: Martins Fontes, 2002.

Direito de Liberdade. Leitura Moral da Constituição Americana. São Paulo: Martins Fontes, 2006.

GADAMER, Hans-Georg. Verdade e Método. Traços Fundamentais de uma Hermenêutica Filosófica. Tradução de Flávio Paulo Meurer. 3. ed. Petrópolis: Vozes, 1999.

GREY, Thomas C. “Do We Have un Unwritten Constitution?” In: Stanford Law Review n. 27, 1975.

HART, Hebert. O Conceito de Direito. Tradução de A. Ribeiro Mendes. 3. ed. Lisboa: Calouste Gulbenkian, 1996, pp. 89 e segs.

KAUFMANN, Arthur. Introdução à Filosofia do Direito e à Teoria do Direito Contemporâneas. Lisboa: Calouste Gulbenkian, 2002.

KELSEN, Hans. Teoria Pura do Direito. Tradução de João Baptista Machado. São Paulo: Martins Fontes, 1985.

MÁRTIRES COELHO, Inocêncio. Interpretação Constitucional. Porto Alegre: Fabris, 1992.

OLIVEIRA, Manfredo Araújo de. Reviravolta Lingüístico-pragmática na Filosofia Contemporânea. São Paulo: Loyola, 2001.

SARMENTO, Daniel. Interpretação Constitucional, Pré-Compreensão e Capacidades Institucionais do Intérprete. In: Vinte Anos da Constituição Federal de 1988. Claudio Pereira de Souza Neto, Daniel Sarmento e Gustavo Binembojn (Org.) Rio de Janeiro: Lumen Juris, 2009.

STEIN, Ernildo. Uma Breve Introdução à Filosofia. 2. ed. Ijuí: Unijuí, 2005.

STRECK, Lenio Luiz. Verdade e Consenso. Constituição, Hermenêutica e Teorias Discursivas da Possibilidade à necessidade de respostas corretas em Direito. 3. ed. Rio de Janeiro: Lumen Juris, 2009.

Jurisdição Constitucional e Hermenêutica. 2. ed. Rio de Janeiro: Forense, 2004. 